\title{
The great and silent revolution of the units of measure
}

\section{F Passariello 1}

${ }^{1}$ Fondazione Vasculab ONLUS, via Francesco Cilea 280 - 80127 Naples, Italy

submitted: Apr 14, 2019, accepted: Apr 17, 2019, EPub Ahead of Print: Apr 18, 2019, published: Jul 7, 2019

Conflict of interest: None

DOI: 10.24019/jtavr.32 - Corresponding author:Dr. Fausto Passariello, afunzionale@tiscalinet.it

(C) 2018 Fondazione Vasculab impresa sociale ONLUS. All rights reserved.

Maybe just a few people know that on May $20^{\text {th }}, 2019$ a global revolutionary change of the units of measure will involve all human activities everywhere in the world.

No panic, please ! Nothing at all will really change in our daily life.

The current revolution started in France, but almost all the states of the world joined the Committee (Table I). As

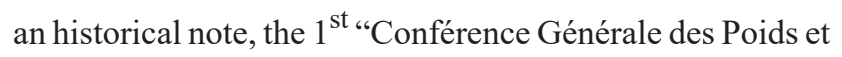
Mesures" [General Conference on Weights and Measures] $(\mathrm{CGPM})^{1}$ was held in 1899 in Paris $^{2}$ while the $26^{\text {th }}$ CGPM was organised in 2018 in Versailles Nov $13^{\text {th }}-16^{\text {th }}$ by the "Bureau Internationale des Poids et Mesures" [International Bureau of Weights and Measures] (BIPM), which published a final document about the adopted resolution ${ }^{3}$.

In detail, the International System of Units (SI) was previously defined in 1960 with six basic units, replacing the old CGS and MKS system ${ }^{[i]}$ and was continuously updated in the following years. The current 2018 update, taking effect from May 20, 2019, introduces new definitions for seven basic units, which use the three universal physical constants G (gravitational constant), h (quantum Planck constant) and $\mathbf{c}$ (light speed in vacuum and relativistic constant).

The differences between the current and the previous definitions are summarized in Table II.

The echo of the current resolution reached the specialized public through articles ${ }^{4}$ and the organization of events. An interesting exhibition is currently held at the "Conservatoire National des Arts et Métiers" [National Museum of Arts and Works] $]^{5,6}$. The Conservatoire was founded in 1794 by the "Abbey Grégoire", during the French revolution, when the interest for the units of measure was firstly officially stated.

The Museum hosts also the Lavoisier chemical laboratory and one realization of the famous Foucault Pendulum (1851), used to show the rotation of the Earth and the Coriolis effect. The exposition will be open until May $5^{\text {th }}, 2019$ - just fifteen days before the deadline for the new 2019 SI change.

Visiting the exposition, we learn how the history of the civil society is weaved together with the units of measure, being unexpectedly connected to the history of taxation. Governments have a great interest in measurements, in order to be able to apply a certain and an undoubted fee, according to a fixed unit of measure.

Here we see displayed a lot of unit devices which were used in the past, for instance by the Egyptians, Greeks and Romans to document this indissoluble relationship. Other similar devices are also in exhibition from more recent epochs, like the medieval and renaissance ages.

The need to set a supranational standard was clearly felt during the French revolution. At the time the units of measure just then were scarcely precise and only locally valid. It could be hypothesized that the great interest for the units of measure maybe rose during the French revolution in order to provide the same scientific measurements everywhere in the French Republic and for all the citizens, as intellectually required by the Enlightenment age.

Later and gradually at the end of the XIX century all countries agreed to participate in setting a standard in measurements and joined the BIPM. 


\section{International Committee for Weights and Measures (CIPM)}

\section{List of Member States}

Argentina, Australia, Austria, Belgium, Brazil, Bulgaria, Canada, Chile, China, Colombia, Croatia, Czechia, Denmark, Egypt, Finland, France, Germany, Greece, Hungary, India, Indonesia, Iran (Islamic Republic of), Iraq, Ireland, Israel, Italy, Japan, Kazakhstan, Kenya, Korea (Republic of), Lithuania, Malaysia, Mexico, Montenegro, Netherlands, New Zealand, Norway, Pakistan, Poland, Portugal, Romania, Russian Federation, Saudi Arabia, Serbia, Singapore, Slovakia, Slovenia, South Africa, Spain, Sweden, Switzerland, Thailand, Tunisia, Turkey, Ukraine, United Arab Emirates, United Kingdom, United States of America, Uruguay

\section{List of Associated States and Economies}

Azerbaijan, Bangladesh, Belarus, Bolivia, Bosnia and Herzegovina, Botswana, Caribbean Community, Chinese Taipei, Costa Rica, Cuba, Ecuador, Estonia, Ethiopia, Georgia, Ghana, Hong Kong (China), Jamaica, Kuwait, Latvia, Luxembourg, Mauritius, Moldova (Republic of), Mongolia, Namibia, North Macedonia, Oman, Panama, Paraguay, Peru, Philippines, Qatar, Seychelles, Sri Lanka, Sudan, Syrian Arab Republic, Tanzania (United Republic of), Uzbekistan, Viet Nam, Zambia, Zimbabwe

Table I

Coming back to more recent times, the current change in the SI is not a simple negligible update. It is an important revolution instead, because several units are redefined and some of them are substituted by the universal physical constants.

For instance, using the old definition of meter (based on the standard example meter made of platinum-iridium and kept in Sèvres, France), the development of the Global Positioning System (GPS) technology would never have been possible, while it was realized using the new unit, given by the standard speed of light in vacuum. Note that in this case the velocity substitutes the length in the definition, while the basic physical quantity is still the length.
However, the revolution of the units of measure mainly deals with high precise technical applications, while it does not involve any change in our ordinary daily measure, as the length of a table, the weight and the circumference of the ankle of a patient.

Thus, all instruments remain valid and in the same way all the usual daily procedures are still correct.

In this sense the new SI update is a great-but-silent revolution in Metrology.

Fausto Passariello

Editor in Chief of JTAVR

\section{Endnotes}

[i] The (centimeter, gram, second) system (CGS) was adopted in 1873 by the British Association for the Advancement of Science as an evolution of the previous (millimetre, milligram, second) system, proposed in 1832 by Carl Friedrich Gauss. The CGS system was later substituted by the (meter, kilogram, second) system (MKS) during the $1^{\text {st }}$ CGPM meeting in 1899 . However, it was internationally accepted only in 1940 and suddenly substituted in 1960 by the International System of Units (SI). Today, CGS and MKS survive as non-official systems in specialised fields of science, where several units are felt as more practical. For instance, blood viscosity is often measured in centipoise $(\mathrm{cP})$, a derived unit of the CGS system. 


\section{New revision of the International System of Units (SI)}

\section{Physical quantity}

Mass

Length

Time

Electric charge

Temperature

Mole

Light intensity

\section{Old unit}

Platinum kilogram $(\mathrm{Kg})$

Platinum meter (m)

Second (s)

Coulomb (C)

Kelvin (K)

Mole (mol)

Candela (cd)

\section{New unit}

Planck constant (h)

Speed of Light in vacuum (c)

Transition frequency of Caesium 133 atom (Cs)

Ampère per second

Boltzman constant $(\mathrm{k})$

Avogadro constant $\left(\mathrm{N}_{\mathrm{A}}\right)$

Light efficacy of a monochromatic ray $\left(\mathrm{K}_{\mathrm{cd}}\right)$

Table II

\section{References}

1) $26^{\text {th }}$ Conférence générale des poids et mesures (General Conference of weights and measures, CGPM), Versailles Nov 13-16, 2018. Available at the address https://www.bipm.org/fr/cgpm-2018/ accessed Apr 14, 2019.

2) Compte rendus des séances de la première conférence générale des poids et mesures réunie à Paris en 1889 [Report of the sessions of the first general conference of weights and measures in Paris 1889]. Gauthier-Villars Ed, Paris, 1990. Available at the address https://www.bipm.org/utils/common/pdf/CGPM/CGPM1.pdf accessed Apr 14, 2019.
3) CGPM adopted resolutions. Available at the address https://www.bipm.org/utils/common/pdf/CGPM-2018/26thCGPM-Resolutions.pdf accessed Apr 14, 2019.

4) BIPM brochure. Available at the address https:// www.bipm.org/fr/publications/si-brochure/ accessed Apr 14, 2019.

5) Exhibition at the "Conservatoire National des Arts et Métiers" [National Museum of Arts and Works], 60 rue Réaumur, 75003 Paris. Exposition from Oct 16, 2018 to May 5, 2019. Info at the address http://www.arts-et-metiers.net accessed Apr 14, 2019.

6) Les unités de mesure font leur révolution [The units of measure make their revolution]. CNRS Le Journal. 2018 summer;293:3-11. 